\title{
In Vitro Regeneration of Plectranthus Edulis (Vatke) from Leaf Derived Callus
}

\author{
Nitsuh Aschale Tileye Feyissa $^{2}$ \\ Institute of Biotechnology, Addis Ababa University, Addis Ababa, Ethiopia
}

\begin{abstract}
Plectranthus edulis (Vatke) Agnew is a tuber-bearing food in Ethiopia and used as a traditional medicine to treat different diseases. Vegetative propagated plants are mostly affected by different diseases. The establishment of $i n$ vitro plant regeneration system in $P$. eduils is of potential importance to genetically improve this plant using different biotechnological approaches including genome editing and genetic transformation. Best calli (100\%) were obtained on MS medium supplemented with $1.5 \mathrm{mg} / 1 \mathrm{NAA}+1.0 \mathrm{mg} / 1 \mathrm{BAP}$ and $2.0 \mathrm{mg} / 1 \mathrm{NAA}+0.5 \mathrm{mg} / \mathrm{l} \mathrm{BAP}$. For multiplication, maximum $(58.68 \pm 6.57)$ mean numbers of shoots were obtained on $0.5 \mathrm{mg} / \mathrm{l} \mathrm{BAP}$ in

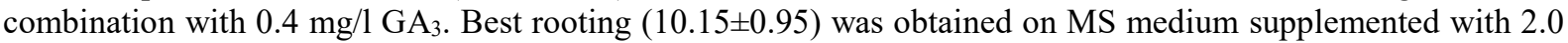
$\mathrm{mg} / \mathrm{l}$ IBA. After a month, all in vitro rooted and $78 \%$ of microshoots were survived in the glasshouse. This protocol can be used to improve this plant through in vitro screening, genome editing and genetic transformation.
\end{abstract}

Keywords: callus induction, growth regulator, organogenesis, regeneration.

DOI: $10.7176 / \mathrm{JBAH} / 9-5-03$

Publication date:March $31^{\text {st }} 2019$

\section{INTRODUCTION}

Plectranthus edulis is an indigenous tuber crops in Ethiopia. It is a diploid, dicotyledonous plant and occurs as wild. It can grow at the mid to high altitude areas in the south, north and south-west of Ethiopia (Taye, 2008).

P. eduils is one of the local tubers in Ethiopia (IBC, 2005) and has a long history of local usage. It is important to the cultural, social and economic life of households (Demissie, 1988) and also traditionally recommended as a special food in the community for people who are recovering from illness, probably owing to its high digestibility. It is also reported that it has no impact on the stomach whatever amount is consumed (Mekbib and Webiull, 2012) and serves as medicinal plant.

In vitro propagation of P.edulis using meristem (Tsgaw and Feyisaa, 2014), nodal and shoot tip culture (Kebede and Abera, 2014) have been reported earlier but, both of them works on mass propagation of this tuber plant. Just like any other vegetativelly propagating crops, $P$. edulis is affected by diseases like virus, fungi, bacteria, insects and nematodes contributing to significant yield loss (Wharton and Kirk, 2007). Application of modern biotechnologies in $P$. eduils would be decisive to improve the quality as well as quantity of this tuber by means of producing plants resistant to different diseases through in vitro screening, genome editing and genetic engineering. These are performed by utilization (exploitation) of genome modification, gene transfer by genetic transformation, in vitro screening of somaclonal variants and somatic hybridization which requires the control of plant regeneration from tissue culture techniques. Therefore, development of a reliable in vitro plant regeneration procedure is a prerequisite for its genetic improvement by creating genetic variability via biotechnological methods (Sihachakr et al., 1997). Success of any transformation strategy depends largely upon the regeneration capability of the target explants (Chugh and Khurana, 2003).

Therefore, the objective of the present study was to develop in vitro regeneration protocol for P. edulis using leaf as explant.

\section{Materials and Methods}

\subsection{Callus Induction}

About $5 \mathrm{~mm}$ long young leaves were excised from thirty-day-old in vitro propagated $P$. eduils shoots. The leaves were wounded perpendicular to the midrib with scalpel and cultured on MS medium (Murashige and Skoog, 1962) supplemented with different concentrations of NAA $(0.0,0.01,0.1,0.5,1.5,2.0 \mathrm{mg} / \mathrm{l})$ and BAP $(0.0,0.1,0.5,1.0$, $1.5,2.0 \mathrm{mg} / \mathrm{l})$ with adaxial surface of the leaves in contact with the medium. Growth regulators free medium was used as control. Ten leaves per Petri dish and 10 replications for each treatment were used. After four weeks, the number of leaves that induced callus was recorded.

\subsection{Shoot regeneration}

Calli induced on callus induction medium were transferred to MS medium supplemented with different concentrations of BAP $(0.0,0.1,0.5,1.0$ and $1.5 \mathrm{mg} / \mathrm{l})$ and TDZ $(0.0,0.1,0.5$ and $1.0 \mathrm{mg} / \mathrm{l})$ for shoot regeneration. After a month, these calli were transferred to the same fresh MS medium. All the cultures were kept at $25 \pm 2^{\circ} \mathrm{C}$ under dark condition until the shoots arose from calli. After six weeks, when shoots were regenerated from calli, the cultures were kept under dim light $\left(20 \mu \mathrm{mol} \mathrm{m} \mathrm{m}^{-2} \mathrm{~s}^{-1}\right.$ for one week and then transferred into full light of $40 \mu \mathrm{mol}$ 
$\mathrm{m}^{-2} \mathrm{~s}^{-1}$ and $16 \mathrm{~h}$ photoperiod. After eight weeks, number of calli that produced shoots, number of shoots per callus and shoot length per regenerated shoot were recorded.

\subsection{Shoot multiplication}

Regenerated shoots were cultured in Magenta GA-7 culture vessels containing $40 \mathrm{ml}$ of the MS medium. The medium was supplemented with different concentrations of BAP $(0.0,0.1,0.2,0.3,0.4,0.5,0.8,1.0,1.5,2.0,3.0$ $\mathrm{mg} / \mathrm{l})$, TDZ $(0.0,0.1,0.2,0.4,0.5,1.0,1.5 \mathrm{mg} / \mathrm{l})$ and $\mathrm{GA}_{3}(0.0,0.01,0.1,0.5,1.0,2.0 \mathrm{mg} / \mathrm{l})$ were used for shoot multiplication either alone or in combination. Eight shoots per Magenta and four replications for each treatment were used. Number and length of shoots per explant were recorded after four weeks.

\subsection{Rooting}

About 3-5 cm long shoots that were multiplied on shoot multiplication medium were cultured on MS basal medium supplemented with variable concentrations of IBA $(0.0,0.1,0.2,0.3,0.4,0.6,1.0,1.5$ and $2.0 \mathrm{mg} / \mathrm{l})$. Eight shoots per Magenta and four replications for each treatment were used. After four weeks, number and length of the roots were recorded.

\subsection{Acclimatization}

In vitro rooted shoots were removed from rooting medium and the roots were washed under running tap water. For ex vitro rooting, about $4 \mathrm{~cm}$ long microshoots were used. They were transferred to small pots filled with red soil, sand and compost in 2:1:1 ratio, respectively. Eight shoots per pot and thirteen replications were acclimatized for both in vitro rooted shoots and microshoots.

Pots containing both in vitro rooted plantlets and microshoots were covered with polyethylene bags. Polyethylene bags were partially removed after a week and completely removed after two weeks. The plantlets were watered every day using sprayer and kept for four weeks in glasshouse. After four weeks, number of survived plants were recorded and transferred to open sunshine. Finally, the number of plants that survived in the open sunshine was also recorded after a month.

\section{Data analysis}

Completely randomized design was used throughout this experiment (CRD). The one-way analysis of variance (ANOVA) was used to compute mean number of regenerated shoots, shoot multiplication, the number and length of roots and their survival rate in glasshouse. All data were analyzed at $p<0.05$ using SPSS version 14 statistical software. Data were subjected to analysis of variance and variables that showed significant difference were compared by the LSD at $5 \%$ probability.

\section{Results and Discussion}

\subsection{Callus induction}

Callus induction was observed within four weeks of culture from leaf explants on MS medium containing different concentrations and combinations of NAA and BAP. Among variable combinations of PGRs, the maximum calli (100\%) were recorded on MS medium supplemented with $1.5 \mathrm{mg} / \mathrm{l}$ and $2.0 \mathrm{mg} / \mathrm{l} \mathrm{NAA}$ in combination with 1.0 $\mathrm{mg} / \mathrm{l}$ and $0.5 \mathrm{mg} / \mathrm{l} \mathrm{BAP}$, respectively. Except the control (PGRs free medium) all combinations of PGRs induced calli. The rate of callus induction was significantly different among combination of plant growth regulators.

The callus thus obtained was compact and white in colour. The size and the shape of the explant were also changed into dome shape. Callus was induced on the leaves at the sites wounded with scalpel perpendicular to the midrib and finally covered the whole leaf. Similar results were reported by Sharma et al. (2012) that callus was initiated from longitudinally injured surface of the leaf and also proliferated from cut end of Ephedra gerardiana explants. Feyissa et al. (2005) also reported that wounding promoted earlier callus formation. However, it is critical to ensure that, in such cases, wounding does not negatively affect regeneration potential (Zimmerman and Fordham, 1985).

In the present study, all combinations of NAA and BAP induced better calli. This result agrees with the report of Tejavathi and Indira (2013), in which BAP in combination with NAA promoted callus in Drymaria cordata plant. Martel et al. (1992) on Solanum tuberosum L. cv. Sebago and Yasmin et al. (2003) on potato plantlets also reported that NAA was essential for callus induction and the amount of callus induction increased with increased concentration of NAA and BAP.

According to Yasmin et al. (2003), percentage of callus induction was highest (95\%) in MS medium containing $2.0 \mathrm{mg} / \mathrm{l} \mathrm{BAP}$ in combination with $2.5 \mathrm{mg} / \mathrm{l} \mathrm{NAA}$ from leaf explants of potato. Other similar responses were reported by Onamu (2012), where $100 \%$ of callus was induced using nodal explants of potato (Solanum tuberosum L.) cultivars grown in Mexico with $4.0 \mathrm{mg} / 1$ BAP in combination with $1.0 \mathrm{mg} / 1 \mathrm{NAA}$. Contrasting results were reported on tissue culture of Solanum melongena L., where callus formation was optimum when MS medium was supplemented with low concentration of NAA and high concentration of BAP (Ray et al., 2011). 
Table 1 Percentage of calli induced from leaf explants of $P$. eduils

\begin{tabular}{lcc}
\hline NAA & Growth regulators $(\mathbf{m g} / \mathbf{l})$ & Callus induction $\%$ \\
\hline 0.0 & BAP & \\
0.01 & 0 & 0 \\
0.01 & 0.1 & 30 \\
0.01 & 0.5 & 60 \\
0.01 & 1.0 & 69 \\
0.1 & 2.0 & 96 \\
0.5 & 0.1 & 80 \\
0.5 & 0.5 & 67 \\
1.5 & 1.5 & 96 \\
1.5 & 0.1 & 74 \\
2.0 & 1.0 & 100 \\
\hline
\end{tabular}

\subsection{Shoot regeneration}

After six weeks of culturing of calli on shoot regeneration medium, shoot formation was observed from those calli that were induced on MS medium containing NAA $(0.01,0.5$ and $1.5 \mathrm{mg} / 1)$ in combination with BAP $(1.0,0.5$ and $0.1 \mathrm{mg} / \mathrm{l})$, respectively. However, combination of NAA $(0.0,0.01,0.1,0.5,1.5,2.0 \mathrm{mg} / \mathrm{l})$ and BAP $(0.0,0.1,0.5$, $1.0,1.5,2.0 \mathrm{mg} / \mathrm{l})$ calli didn't regenerate any shoots. The frequency of shoot regeneration was influenced by the concentrations of NAA and BAP. The highest shoot regeneration frequency (46.6\%) was obtained on MS medium supplemented with $0.1 \mathrm{mg} / 1 \mathrm{BAP}$ in combination with $0.5 \mathrm{mg} / 1 \mathrm{TDZ}$. The highest mean shoot number per callus $(1.66 \pm 1.04)$ and length $(0.63 \pm 0.19 \mathrm{~cm})$ were obtained on MS medium supplemented with $1.5 \mathrm{mg} / \mathrm{BAP}+1.0 \mathrm{mg} / 1$ TDZ and $0.5 \mathrm{mg} / \mathrm{l} \mathrm{BAP}+0.1 \mathrm{mg} / \mathrm{lDZ}$, respectively. However, shoots were not regenerated from calli that were cultured on PGRs free medium. Similar result was reported by Yasmin et al. (2003) who stated that PGRs free medium did not regenerate shoots on leaf and internodal segment of potato.

The result of this study revealed that there was no relationship between callus formation ability and shoot regeneration. Furthermore, shoots were regenerated from calli that were derived from longitudinally wounded leaves. Ganesan and Jayabalan (2005) pointed out that leaf explants exhibited a low ability to form callus, but leaf derived calli regenerated shoots at a relatively high percentage on shoot tips in cotton plant. Additionally, whole leaf explants wounded along the midribs were more regenerative than stem in leaves of wild pear (Bhagwat and Lane, 2004).

In the present study, 30 shoots per callus was the maximum number of shoots recorded on $P$. eduils plant. But, Khalafalla et al. (2010); Getu and Feyisa (2012) reported that two shoot per calli was the maximum number of shoots observed on potato (Solanum tuberosum L.) cultivar 'Almera' and sweet potato variety 'Beletech', respectively.

Table 2. Percentage of regeneration, mean number and height of regenerated shoots from calli of $P$. eduils Values are given as mean $\pm \mathrm{SE}$

\begin{tabular}{lllll}
\hline \multicolumn{2}{l}{$\begin{array}{l}\text { Conc. of } \\
\text { PGRs (mg/l) }\end{array}$} & $\begin{array}{l}\text { Percentage of } \\
\text { Regeneration } \\
\%\end{array}$ & Mean shoot number per callus & $\begin{array}{l}\text { Mean shoot height } \\
(\mathrm{cm})\end{array}$ \\
\hline BAP & TDZ & $\%$ & $0 \pm 0^{\mathrm{bcd}}$ & $0 \pm 0^{\mathrm{c}}$ \\
0 & 0 & 0 & $0.46 \pm 0.92^{\mathrm{ac}}$ & $0.60 \pm 0.15^{\mathrm{ab}}$ \\
0.1 & 0.5 & 46.6 & $1.66 \pm 1.04^{\mathrm{a}}$ & $0.09 \pm 0.04^{\mathrm{c}}$ \\
0.5 & 1 & 13.3 & $1.36 \pm 0.87^{\mathrm{ab}}$ & $0.63 \pm 0.19^{\mathrm{a}}$ \\
1.5 & 0.1 & 30 & $0.26 \pm 0.17^{\mathrm{ad}}$ & $0.25 \pm 0.12^{\mathrm{c}}$ \\
0.5 & 0.1 & 13.3 & $0.13 \pm 0.10^{\mathrm{bcd}}$ & $0.06 \pm 0.05^{\mathrm{c}}$ \\
\hline
\end{tabular}

Means within each column connected by the same superscript (a-d) are not significantly different at $5 \%$ probability level. 


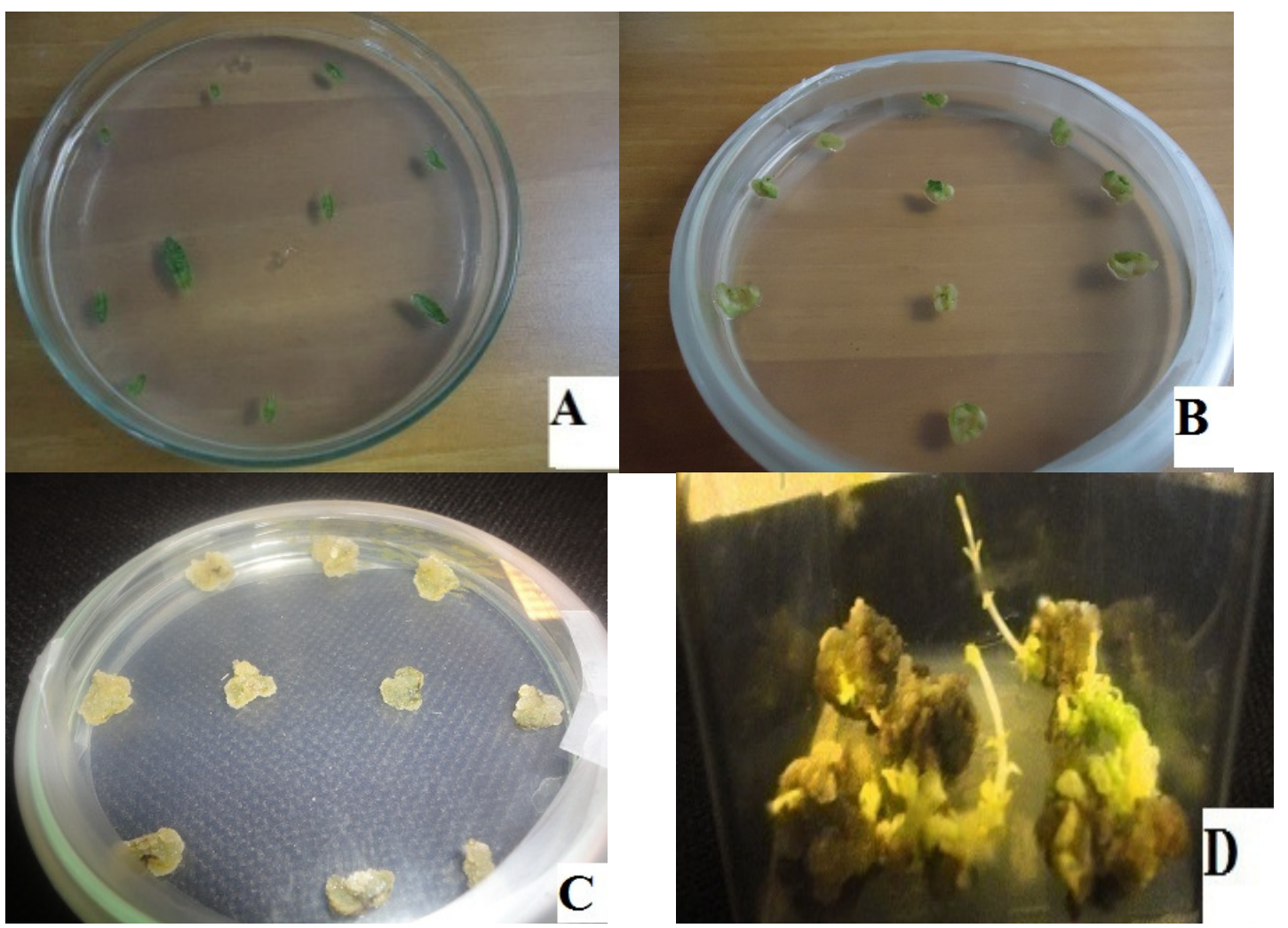

Figure 1. Calli formation and shoot regeneration of $P$. edulis from leaf explants. (A) Leaf explants cultured adaxially on MS medium supplemented with $0.01 \mathrm{mg} / 1 \mathrm{NAA}$ in combination with $1.0 \mathrm{mg} / \mathrm{l} \mathrm{BAP}$; (B) Three-weekold calli; (C) Four-week-old calli; (D) Six-week-old regenerated shoots after transferred to MS medium supplemented with $0.1 \mathrm{mg} / 1 \mathrm{BAP}$ combined with $0.5 \mathrm{mg} / 1 \mathrm{TDZ}$.

\subsection{Shoot Multiplication}

Shoot number and length were highly influenced by concentrations and types of PGRs. Among all treatments used, highest mean shoot number (58.68 \pm 6.57$)$ and number of shoots per explants (129) were obtained on MS medium supplemented with $0.5 \mathrm{mg} / \mathrm{l} \mathrm{BAP}+0.4 \mathrm{mg} / 1 \mathrm{GA}_{3}$. Duraisamy et al. (2012) also reported that maximum mean number of shoots per explant (6.3 \pm 0.09 ) was obtained using MS medium supplemented with $0.02 \mathrm{mg} / \mathrm{l} \mathrm{GA}+0.1$ $\mathrm{mg} / \mathrm{l} \mathrm{BAP}$ on apical meristem cultures of cassava. Tsgaw and Feyisaa (2014) obtained the maximum mean number of shoots per explant (7.2) of $P$. edulis on MS medium supplemented with $1.0 \mathrm{mg} / 1 \mathrm{KIN}+0.1 \mathrm{mg} / 1 \mathrm{NAA}$. And also, Kebede and Abera (2014) reported that best number of shoot proliferation $10.28 \pm 0.06$ and $6.12 \pm 0.01$ was obtained on MS medium containing $2.0 \mathrm{mg} / \mathrm{l} \mathrm{BAP}$ and $1.0 \mathrm{mg} / \mathrm{l} \mathrm{NAA}$ from nodal and shoot tip culture of P.edulis, respectively.

Hence, this difference might be, the shoots obtained via callus may be more juvenile and are suitable for mass propagation. A similar response was mentioned by Zhao (2008) that shoots derived from callus were found to exhibit more shoots.

The multiplication rate of $P$. edulis on a medium containing BAP in combination with $\mathrm{GA}_{3}$ was relatively higher than that of other PGRs, either used alone or in combinations. Severe chlorosis was observed in the plants cultured on medium containing $1.0 \mathrm{mg} / \mathrm{l} \mathrm{GA}_{3}$ (Rabbani et al., 2001). However, the toxic effect of $\mathrm{GA}_{3}$ was minimized when it was used in combination with BAP. Combination of $0.5 \mathrm{mg} / 1 \mathrm{GA}_{3}$ and $0.5 \mathrm{mg} / \mathrm{l} \mathrm{BAP}$ exhibited best result with almost 1.3 and 1.2 fold increase in shoot numbers and plant height on in vitro regeneration of Solenostemon scutellarioides. This might be the reason for the present study when maximum mean number of shoots per explant $(58.68 \pm 6.57)$ and mean height $(3.90 \pm 0.19 \mathrm{~cm})$ was recorded by combining BAP with $\mathrm{GA}_{3}$. Unlike the result of Getu and Feyisa (2012) who reported that more sweet potato shoots per explant (2.40 \pm 0.113$)$ was obtained on MS medium supplemented with $1.0 \mathrm{mg} / 1$ BAP than those cultured on medium containing $\mathrm{GA}_{3}$ combined with BAP. Badoni and Chauhan (2009) also reported that $\mathrm{GA}_{3}$ and NAA combination is best for shoot regeneration and multiplication of potato cv. 'Kufri Himalini' in comparison to using combination of Kinetin and NAA. 
Table 3. Mean number and length of shoots induced on MS medium containing different concentrations of PGRs. Mean values are indicated as $\pm \mathrm{SE}$

\begin{tabular}{|c|c|c|c|c|}
\hline \multicolumn{3}{|c|}{ Growth regulators $(\mathrm{mg} / \mathrm{l})$} & \multirow{2}{*}{$\begin{array}{l}\text { Mean No. of } \\
\text { shoots/explants }\end{array}$} & \multirow{2}{*}{$\begin{array}{l}\text { Mean shoot } \\
\text { height }(\mathrm{cm})\end{array}$} \\
\hline BAP & $\mathrm{GA}_{3}$ & TDZ & & \\
\hline 0 & 0 & 0 & $3.93 \pm 0.49^{\text {ghi }}$ & $2.06 \pm 0.18^{\text {fh }}$ \\
\hline 0.1 & 1.5 & 0 & $11.31 \pm 0.96^{\mathrm{eg}}$ & $3.67 \pm 0.18^{\mathrm{ab}}$ \\
\hline 0.2 & 0.5 & 0 & $23.34 \pm 2.99^{\mathrm{d}}$ & $3.90 \pm 0.19^{\mathrm{a}}$ \\
\hline 0.3 & 1 & 0 & $15.53 \pm 2.14^{\mathrm{e}}$ & $3.26 \pm 0.17^{\mathrm{bcd}}$ \\
\hline 0.4 & 0.2 & 0 & $42.28 \pm 5.27^{\mathrm{b}}$ & $3.67 \pm 0.12^{\mathrm{ac}}$ \\
\hline 0.5 & 0.4 & 0 & $58.68 \pm 6.57^{\mathrm{a}}$ & $2.98 \pm 0.16^{\mathrm{de}}$ \\
\hline 1 & 0.5 & 0 & $17.81 \pm 2.66^{\mathrm{e}}$ & $2.71 \pm 0.24^{\mathrm{ef}}$ \\
\hline 1.5 & 0.1 & 0 & $34.90 \pm 3.95^{\mathrm{c}}$ & $2.82 \pm 0.15^{\mathrm{de}}$ \\
\hline 0.5 & 0 & 0.01 & $16.28 \pm 1.51^{\mathrm{e}}$ & $1.96 \pm 0.12^{\mathrm{ghi}}$ \\
\hline 0.5 & 0 & 0.1 & $15.90 \pm 1.57^{\mathrm{e}}$ & $1.75 \pm 0.09^{\mathrm{ghl}}$ \\
\hline 0.5 & 0 & 1 & $6.93 \pm 0.73^{\text {fghi }}$ & $3.14 \pm 0.21^{\text {bce }}$ \\
\hline 0.5 & 0 & 0 & $5.40 \pm 0.97^{\text {fghi }}$ & $1.83 \pm 0.14^{\text {ghk }}$ \\
\hline 0.8 & 0 & 0 & $7.50 \pm 0.78^{\text {fghi }}$ & $2.09 \pm 0.15^{\mathrm{fg}}$ \\
\hline 2 & 0 & 0 & $11.21 \pm 0.77^{\mathrm{ef}}$ & $1.32 \pm 0.08^{\mathrm{jkln}}$ \\
\hline 3 & 0 & 0 & $7.09 \pm 0.83^{\text {fghi }}$ & $1.81 \pm 0.59^{\mathrm{ghj}}$ \\
\hline 0 & 0 & 0.5 & $10.28 \pm 1.05^{\mathrm{ei}}$ & $1.32 \pm 0.08^{\mathrm{ijklm}}$ \\
\hline 0 & 0 & 1 & $10.06 \pm 1.59^{\mathrm{eh}}$ & $1.02 \pm 0.09^{\mathrm{mn}}$ \\
\hline 0 & 0 & 2 & $3.96 \pm 0.69^{\mathrm{ghi}}$ & $0.44 \pm 0.06^{\circ}$ \\
\hline
\end{tabular}

Means connected by the same superscript letters (a-o) in the same column are not significantly different at $5 \%$ probability level.
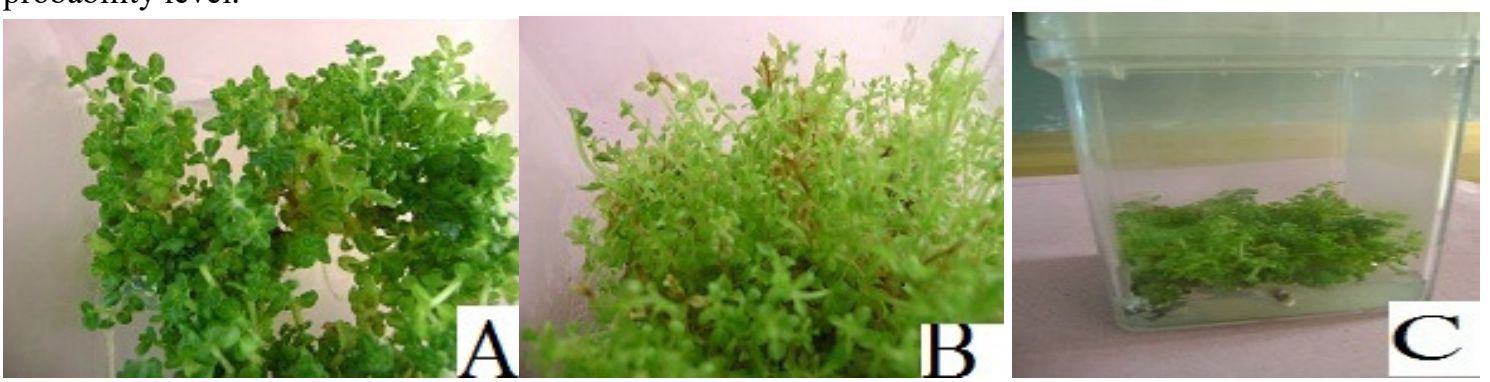

Figure 2. Shoot multiplication from regenerated shoots. (A) $0.5 \mathrm{mg} / \mathrm{l} \mathrm{BAP}+0.01 \mathrm{mg} / \mathrm{l} \mathrm{TDZ}$; (B) $0.4 \mathrm{mg} / 1 \mathrm{BAP}+$ $0.2 \mathrm{mg} / 1 \mathrm{GA}_{3}$; (C) $2.0 \mathrm{mg} / \mathrm{l} \mathrm{BAP}$

\subsection{Rooting}

The shoots that were cultured on MS basal medium supplemented with different concentrations of IBA showed different rooting responses. Among the nine variable concentrations of IBA used, the highest mean number of roots per explant $(10.15 \pm 0.95)$ and mean length $(5.06 \pm 0.35 \mathrm{~cm})$ were obtained on MS medium supplemented with $2.0 \mathrm{mg} / \mathrm{l}$ and $0.6 \mathrm{mg} / \mathrm{l} \mathrm{IBA}$, respectively (Table 4 ). All rooting medium, including growth regulators-free medium, induced rooting. Shahzad et al. (2009) described that IBA rooting medium was better than IAA and NAA. Specially, NAA supplemented medium induced thin delicate roots with slow growth and resulted in some callus formation which is considered to be undesirable for ex vitro establishment that was done in Sansevieria cylindrical. In the present study, most of the rooting media resulted in more than $90 \%$ rooting. Khalafalla et al. (2010) reported that all concentrations of IBA used with both full-MS and half-MS strengths on potato (Solanum tuberosum L.) cultivar 'Almera' induced $100 \%$ rooting.

Another report by Tsgaw and Feyisaa (2014) showed that a maximum number of mean roots per explant (3.23) was obtained on MS medium supplemented with $1.0 \mathrm{mg} / 1 \mathrm{IBA}$ in $P$. eduils and resulted in $95 \%$ rooting. In the present study, equal number of mean roots per explants (3.23 \pm 0.82$)$ was recorded but $100 \%$ rooting was obtained on medium containing $1.0 \mathrm{mg} / \mathrm{l} \mathrm{IBA}$. However, maximum mean number of roots per explant $(10.15 \pm 0.95)$ was obtained at $2.0 \mathrm{mg} / \mathrm{lBA}$.

In ex vitro rooting, the overall best result in rooting was observed in ex vitro rooting condition. The highest mean number of roots $(11.86 \pm 0.52)$ and length $(6.45 \pm 0.18 \mathrm{~cm})$ was obtained. On the other hand, Tsgaw and Feyisaa (2014) recorded that maximum mean number of roots (6.17) and length $(3.3 \mathrm{~cm})$ in P. eduils. The reason might be, roots formed in agar have very small number of root hairs and act like "water roots" (Hollings, 1965).

The result of this study also shows the fact that acclimatization of microshoots of $P$. edulis can efficiently replace in vitro rooting. Therefore, direct rooting of microshoots is cost effective method of rooting. 
Table 4. Mean number and length of roots of $P$. eduils obtained on MS medium supplemented with different IBA concentrations. Values are given as mean $\pm \mathrm{SE}$

\begin{tabular}{lll}
\hline IBA $(\mathrm{mg} / \mathrm{l})$ & Mean number of roots per explant & Root length $(\mathrm{cm})$ \\
\hline 0 & $7.78 \pm 0.96^{\mathrm{bcdef}}$ & $1.57 \pm 0.19^{\mathrm{e}}$ \\
0.1 & $9.03 \pm 1.03^{\mathrm{ad}}$ & $2.65 \pm 0.17^{\mathrm{cd}}$ \\
0.2 & $8.37 \pm 0.72^{\mathrm{af}}$ & $3.16 \pm 0.40^{\mathrm{bd}}$ \\
0.3 & $0.68 \pm 0.25^{\mathrm{h}}$ & $0.59 \pm 0.27^{\mathrm{e}}$ \\
0.4 & $9.09 \pm 7.83^{\mathrm{ac}}$ & $3.53 \pm 0.35^{\mathrm{b}}$ \\
0.6 & $9.93 \pm 0.70^{\mathrm{ab}}$ & $5.06 \pm 0.35^{\mathrm{a}}$ \\
1.0 & $3.59 \pm 0.83^{\mathrm{g}}$ & $1.57 \pm 0.40^{\mathrm{e}}$ \\
1.5 & $8.03 \pm 0.82^{\mathrm{ae}}$ & $4.31 \pm 0.31^{\mathrm{a}}$ \\
2.0 & $10.15 \pm 0.95^{\mathrm{a}}$ & $3.26 \pm 0.30^{\mathrm{bc}}$ \\
\hline
\end{tabular}

Means within each column connected by the same superscript (a-f) are not significantly different at $5 \%$ probability level.

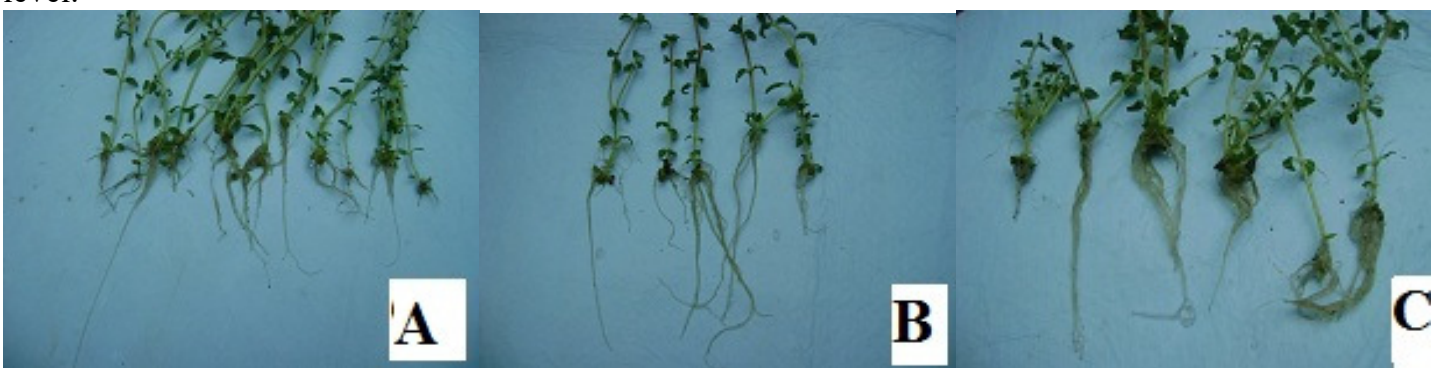

Figure 3. Shoots of $P$. edulis rooted on rooting media containing different concentrations of PGRs. (A) $0.3 \mathrm{mg} / 1$ IBA; (B) $0.6 \mathrm{mg} / 1 \mathrm{IBA}$ and (C) $2.0 \mathrm{mg} / 1 \mathrm{IBA}$

\subsection{Acclimatization}

The plantlets produced in vitro are highly susceptible to the ex vitro condition until they develop adaptation mechanisms to cope with the environmental stress. In the present study, $100 \%$ survival rates of the plantlets were observed in the glasshouse as well as the external environment. The result is consistent with the work of Getu and Feyisa (2012) on sweet potato and Tsgaw and Feyisaa (2014) on P. eduils.

Acclimatization of microshoots was evaluated in the glasshouse and then transferred to the external environment. Among the total plantlets used, $78 \%$ of plantlets survived in the glasshouse as well as in the open sunshine (Fig. 4). The reason for high rate of survival could be due to the ability of $P$. eduils to propagate through vegetative means. Tsgaw and Feyisaa (2014) demonstrated that ex vitro rooting by immersing the microshoots into $5 \mathrm{mg} / \mathrm{l}$ of IBA for 5 minutes before acclimatization resulted in $76.6 \%$ survival of $P$. eduils. The rooting and acclimatization methods of the present study reduce the cost of rooting hormones. 

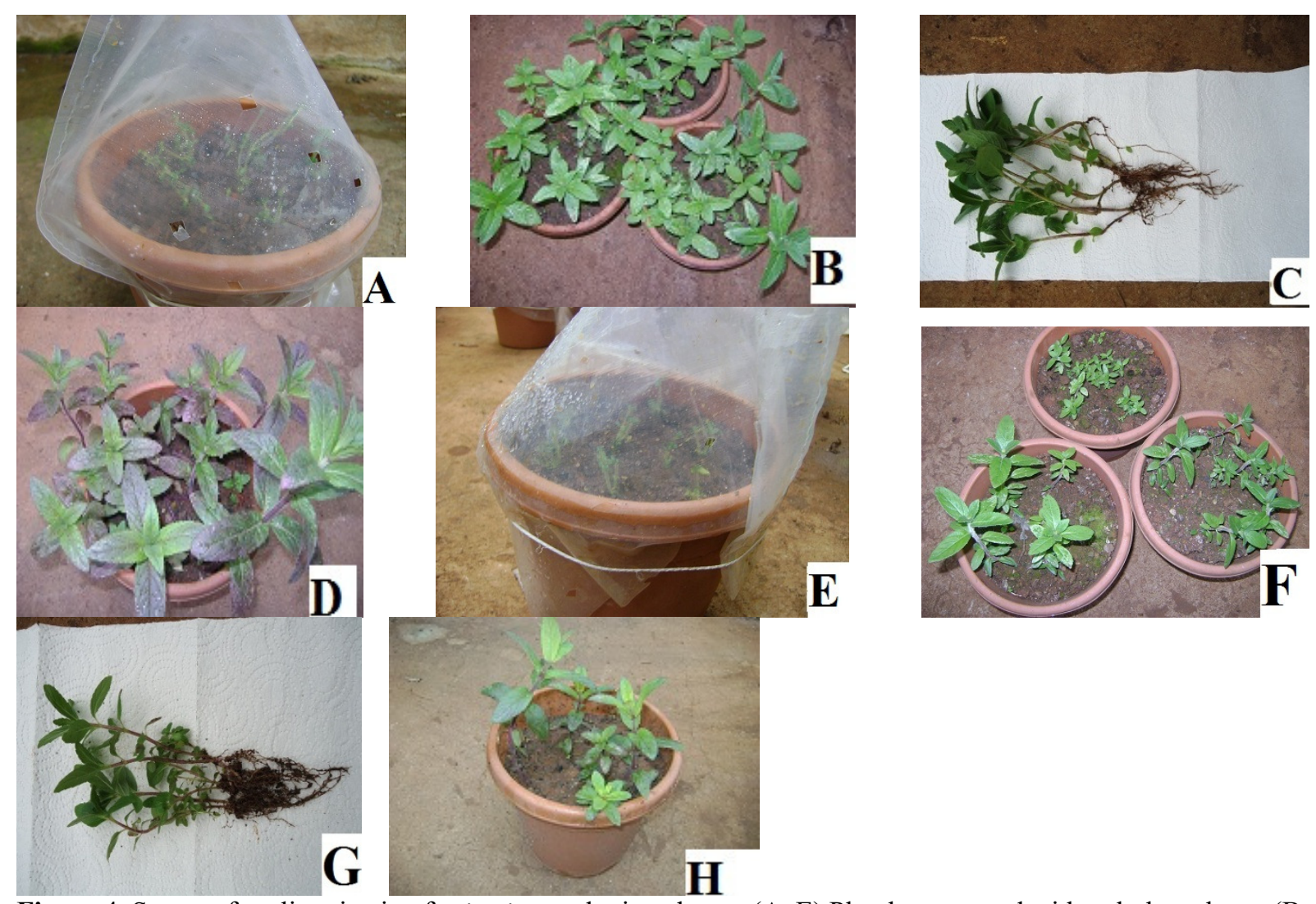

Figure 4. Stages of acclimatization for in vitro and microshoots. (A, E) Plantlets covered with polythene bags; (B, F) Four weeks after acclimatization; $(\mathrm{C}, \mathrm{G})$ Rooted shoots after four weeks; (D, H) After a month, grown in the external environment.

\section{REFERENCES}

Badoni, A. and Chauhan, J. S. (2009). Effect of growth regulators on meristem-tip development and in vitro multiplication of potato cultivar 'Kufri Himalini. Natn. and Sci. 7: 31-34.

Bhagwat, B. and Lane, W.D. (2004). In vitro shoot regeneration from leaves of sweet cherry (Prunus avium) 'Lapins' and 'Sweet heart'. Plant Cell Tiss. Organ Cult. 78: 173-181.

Chugh, A. and Khurana, P. (2003). Herbicide-resistant transgenic of bread wheat (T. aestivum) and emmer wheat (T. dicoccum) by particle bombardment and Agrobacterium-mediated approaches. Current Sci. 8: 78-83.

Demissie, A. (1988). Potentially valuable crop plants in a Vavilovian center of diversity: Ethiopia. pp. 89-98 in Crop Genetic Resources of Africa.

Duraisamy, R., Natesan, S., Muthurajan, R., Gandhi, K., Lakshmanan, P., Karuppusamy, N. and Chokkappan, M. (2012). Molecular Studies on the Transmission of Indian Cassava Mosaic Virus (ICMV) and Sri Lankan Cassava Mosaic Virus (SLCMV) in Cassava by Bemisiatabaci and Cloning of ICMV and SLCMV Replicase Gene from Cassava. Mol. Biotechnol.

Feyissa, T., Welander, M. and Legesse Negash (2005). In vitro regeneration of Hagenia abyssinica (Bruce) J.F. Gmel. (Rosaceae) from leaf explants. Plant Cell Reports. 24: 392-400.

Ganesan, M. and Jayabalan, N. (2005). In vitro plant regeneration from the callus of shoot tips in cotton (Gossypium hirsutum L. cv. SVPR 2). Iranian J. Biotechnol. 3: 620-624.

Getu, T. and Feyissa, T (2012). In vitro regeneration of sweet potato (Ipomoea batatas (L.) Lam.) from leaf and petiole explants. Ethiop. J. Biol. Sci.11:2.

Hollings, M. (1965). Disease control through virus-free stock. Annu. Rev. Phytopathol. 3: 367-396.

IBC (Institute of Biodiversity Conservation). (2005). National Biodiversity Strategy and Action Plan. Addis Ababa.

Kebede, B. and Abera, B. (2014). Micropropagation of Plectranthus edulis (Vatke) Agnew from shoot tip and nodal explants. Afr. J. Agric. Res.10: 6-13.

Khalafalla1, M. M., Elaleem, K. G. A. and Modawi, R. S. (2010). Callus formation and organogenesis of potato (Solanum tuberosum L.) cultivar Almera. J. Phytol. 2: 40-46.

Martel, A. and Garcia, E. (1992). In vitro formation of adventitious shoots on discs of potato (Solanum tuberosum L. cv. Sebago) tubers. Phyton. Buenos. Aires. 53: 57-64.

Mekbib, Y. and Webuil, J. (2012). Local customary use and management of Ethiopian potato (Plectranthus edulis 
(Vatke) Agnew in Sodo Zuria District, South Ethiopia. Ethnobot. Res. \& App. 10: 381-387

Murashige T., and Skoog, F. (1962). A revised medium for rapid growth and bioassay with tobacco tissue culture. Physiol. Plant 15: 473-497.

Onamu, R., Legaria, J. P., Sahagun, J. C., Rodriguez, J. L. and Perez, J. N. (2012). In vitro regeneration and Agrobacterium-mediated transformation of potato (Solanum tuberosum L.) cultivars grown in Mexico. Plant Tissue Cult. Biotechnol. 22: 93-105.

Rabbani, A., Askari, B., Abbasi, N. A., Bhatti, M., Quraishi, A. (2001). Effect of Growth Regulators on in vitro multiplication of potato. Int. J. Agri. Biol. 3: 181-182.

Ray, B. P., Hassan, L. and Nasiruddin, K. M. (2011).In vitro regeneration of Brinjal cv. Jhumki (Solanum melongena L.). Bangladesh J. Agril. Res. 36: 397-406.

Shahzad, A., Ahmad, N., Rather, M. A., Husain, M. K. and Anis, M. (2009). Improved shoot regeneration system through leaf derived callus and nodule culture of Sansevieria cylindrical. Biol. Plant 53: 745-749.

Sharma, V., Gupta, S. K. and Dhiman, M. (2012). Regeneration of plants from nodal and internodal segment cultures of Ephedra gerardiana using Thidiazuron. Plant Tiss. Cult. Biotechnol. 22: 153-161.

Sihachakr, D., Honda, H. and Yamaguchi, K. (1997). Efficient Agrobacterium tumefaciens-mediated transformation of sweet potato (Ipomoea batatas L.) Lam.) from stem explants using a two-step kanamycin hygromycin. In Vitro Cellular and Develop. Biol. 40: 359-365.

Taye, M. (2008). Studies on agronomy and crop physiology of Plectranthus edulis (Vatke) Agnew. Ph.D. Thesis. Wageningen University, Wageningen.

Tejavathi, D. H. and Indira, M. N. (2013). Regeneration of shoots from leaf callus cultures of Drymaria cordata (L.) Willd ex Roem and Schult. Indian J. Funda. and App. Life Sci. 3: 111-115.

Tsegaw, M. and Feyissa, T. (2014). Micropropagation of Plectranthus edulis (Vatke) Agnew from Meristem Culture. Afr. J. Biotechnol.13:3682-3688.

Wharton, P. and Kirk, W. (2007). Potato diseases. Department of Plant Pathology, Michigan State University, Michigan.

Yasmin, S., Nasiruddin, K. M., Begum, R., and Talukder, S. K. (2003). Regeneration and establishment of potato plantlets through callus formation with BAP and NAA. Asian J. plant Sci. 2: 936-940.

Zhao, P., Wu, F., Feng, F. S. and Wang, W. J (2008). Protocorm-like body (PLB) formation and plant regeneration from the callus culture of Dendrobium candidum Wall ex Lindl. In Vitro Cell. Dev. Biol. Plant 44: 178-185.

Zimmerman, H. R. and Fordham, I. (1985). Simplified method for rooting of apple cultivars in vitro. J. Am. Soc. Hort. Sci. 110:34 